\title{
WHITE-TAILED BUCK ATTEMPTS TO MATE WITH WOUNDED DOE
}

\author{
WILLIAM J. WALLEY, 222 Bossons Avenue, Dauphin, Manitoba. RTN OR2
}

In late November 1954, I went deer hunting along the crest of the Birdtail Valley southwest of Birtle, Manitoba. My father, the late John E. Walley, had wounded a White-tailed Deer (Odocoileus virginianus) doe and I followed it in snow through a heavy tract of mature aspen forest. The animal was haemorrhaging and from time to time it could be seen briefly through the trees. In about 15 minutes, I caught up to it in a small clump of aspen saplings where it was standing with its head out of sight in half metre high brome grass.

The deer was approached almost directly from behind and when I was about 6 metres away, "it" suddenly wheeled around toward me - a buck with a full set of antlers. In a flash, it leaped past me within three metres and bounded away through the saplings. Looking down, the doe, barely alive, was belly down on the ground with her neck extended. Curiously, several tufts of deer hair covered her back where it had been pulled out by the buck. This and additional hair on the ground near her, was estimated to be enough to half fill an ordinary water pail. My father ar- rived shortly and also witnessed this unusual event. None of the 13 men, of some 300 years of deer hunting experience, had ever heard of such deer behaviour. In my opinion, they correctly interpreted the observation: that the doe was in heat and the buck had attempted to get her to her feet to mate.

White-tailed Deer are seasonally polyestrous and normally come into heat in November for only a 24 hour period. If the doe fails to mate, a second estrous occurs about 28 days later. ${ }^{1}$

For their interest and the benefit of their years of experience, I thank posthumously: John E. Walley, Gerald Baskier, Clayton Baskier, Chief Eli Bunn (Birdtail Sioux Indian Reservation), Ken Crew, Wellington W. Dodge, Leroy Dutton, and Eph Salmon. I further extend appreciation to Emest C. Walley, Donald Baskier, Elmor Honey, George A. Salmon, and Bruce Thornton.

1. BANFIELD, A.W.F. 1974. The mammals of Canada. University of Toronto Press. (For the National Museum of Natural Sciences, Ottawa) p. 393.

In an ant's house the dew is a deluge. Persian proverb.

To create a little flower is the labour of ages. William Blake. 